\title{
First isolation of a VIM-producing Klebsiella pneumoniae from a seven-year-old child in Venezuela
}

\author{
Daniel Marcano, ${ }^{1}$ Fernando Pasterán, ${ }^{2}$ Melina Rapoport, ${ }^{2}$ Diego Faccone, ${ }^{2}$ \\ Carmen Ugarte, ${ }^{1}$ Nuris Salgado, ${ }^{1}$, Daisy Payares, ${ }^{1}$ Enza Spadola, ${ }^{1}$ Yoanna López, ${ }^{3}$ \\ Graciela Maggi, ${ }^{3}$ Marcelo Galas, ${ }^{2}$ Damarys Sánchez. ${ }^{1}$
}

\footnotetext{
${ }^{1}$ Sección de Aislamiento e Identificación Bacteriana, Instituto Nacional de Higiene "Rafael Rangel", Caracas, Venezuela.

${ }^{2}$ Servicio Antimicrobianos, Instituto Nacional de Enfermedades Infecciosas "Dr. Carlos Malbran", Buenos Aires, Argentina.

${ }^{3}$ Laboratorio de Bacteriología, Hospital de Niños “J. M. de los Ríos”, Caracas, Venezuela.
}

\begin{abstract}
Background: VIM-type metallo-betalactamases (MBLs) exhibit hydrolytic activity against most betalactam antibiotics, including carbapenems. So far, VIM-type-producing Klebsiella pneumoniae isolates had not been reported in Latin America.

Methodology: In July 2005, a carbapenem-resistant Klebsiella pneumoniae was isolated from a urine sample collected from a 7year-old girl hospitalized at the Hospital de Niños "J. M. de los Ríos" in Caracas, Venezuela. This strain was identified using conventional biochemical tests. The susceptibility analysis was conducted by disk diffusion, and MICs for Imipenem and Meropenem were performed by agar dilution. For the phenotypic detection of MBL we used the Imipenem-EDTA/SMA doubledisk diffusion method. The hydrolytic activity against carbapenems was determined by the Masuda microbiological method. Purified protein was subjected to isoelectric focusing (IEF). Detection of antimicrobial resistance genes was performed by PCR amplification with specific VIM primers.

Results: The strain showed resistance to most betalactam antibiotics, quinolones and amynoglicosides, but remained susceptible to Aztreonam and Cefepime. The use of phenotypic and microbiological methods detected the presence of a metallobetalactamase. By IEF we visualized three bands at pl 5.4, 7.6 and 7.9, corresponding to reduced-spectrum betalactamases, and a band at pl 5.8 that corresponded to the metallobetalactamase. PCR screening of bla genes revealed the presence of blavim, with an amplicon of $261 \mathrm{bp}$. Conclusions: This is the first report of a MBL-mediated carbapenem-resistant Klebsiella pneumoniae in Latin America, which constitutes a public health concern in our region since their transference to other microorganisms with multiple antibiotic resistance mechanisms will increase the antimicrobial resistance problem.
\end{abstract}

Key Words: Klebsiella pneumoniae, VIM, carbapenems, Venezuela.

J Infect Developing Countries 2008; 2(3):241-244.

Received 06 November 2007 - Accepted 19 March 2008.

Copyright (c) 2007 Marcano et al. This is an open access article distributed under the Creative Commons Attribution License, which permits unrestricted use, distribution, and reproduction in any medium, provided the original work is properly cited.

\section{Introduction}

The VIM-type metallo-betalactamases (MBLs) exhibit a wide spectrum of hydrolytic activity against betalactam antibiotics, including carbapenems, and their respective bla genes are located in the variable region of class 1 integrons $[1,2]$. These enzymes, that belong to the B class of Ambler's molecular classification and group 3 of Bush, Jacoby and Medeiro's functional classification, have the following characteristics: they're active against carbapenems; they do not hydrolyse monobactams; they are inhibited by metallic ions' chellant agents such as EDTA; they are not inhibited by clavulanic acid, sulbactam or tazobactam; and they present one or two zinc ions in their active site, which bond to water molecules that intervene in the hydrolytic inactivation of the betalactam ring [3-7]. The most frequent MBLs in America are the VIM type, and they have 12 alelic variants, with the VIM-2 variant the most disseminated worldwide [3]. The first South American VIM was reported in 2002 in Venezuela in Pseudomonas aeruginosa, being found in two hospitals in Caracas and in one in Ciudad Bolívar $[3,8]$.

Until now, most VIM-producing K. pneumoniae are susceptible to Aztreonam (a poor substrate for the VIM MBL) and Gentamicin [9]. So far this type of isolate had not been reported in Venezuela, but now we report a case of a patient with a complicated urinary infection caused by VIM-typeproducing Klebsiella pneumoniae. 


\section{Case Report}

In July 2005, after a Ceftazidime week-long treatment, one carbapenem-resistant strain of Klebsiella pneumoniae (185362) was isolated at the Hospital de Niños "J.M de los Ríos" in Caracas, Venezuela from a urine sample collected by probe from a 7-year-old female patient with a history of a left urethral implant, neurogenic bladder, urethrocystoplasty and repeated urinary infections since April 2005. The strain was submitted to the Instituto Nacional de Higiene "Rafael Rangel" (Caracas, Venezuela) for confirmation of its unusual resistance to Imipenem and Cefoxitin) and later referred to the Instituto Nacional de Enfermedades Infecciosas ANLIS "Dr. Carlos Malbran" (Buenos Aires, Argentina) for additional testing.

The strain was identified using conventional biochemical tests (Difco Laboratories, Detroit, Michigan USA), evaluating glucose and lactose fermentation (Kligler agar), glucose metabolism pathway (MRVP broth), malonate metabolism (Malonate broth), citrate metabolism (Citrate agar), lisine, arginine and ornitine decarboxilation (Moeller decarboxylase broth), urea hydrolysis (Christensen agar), arabinose, ramnose and inositol fermentation (Andrade broth), fenilalanine metabolism (Fenilalanine agar), indole production and motility (MIO agar).

The susceptibility analysis was conducted by disk diffusion according to the Clinical and Laboratory Standards Institute (CLSI) guidelines [10] using Mueller Hinton agar (Difco Laboratories) and Ampicillin, Amoxicillin/Clavulanic Acid, Cefoxitin, Cefotaxime, Ceftazidime, Cefpodoxime, Imipenem, Meropenem, Ciprofloxacin, Gentamicin, Amikacin, Aztreonam disks (Oxoid Ltd). The antimicrobial agents used for susceptibility testing were obtained from standard laboratory powders. MIC for Imipenem (Merck Sharp \& Dohme), Meropenem (Astra Zeneca) and Aztreonam (Bristol Mayers) was performed by agar dilution according to CLSI guidelines [11].

For the phenotypic detection of MBL the Imipenem-EDTA/SMA double-disk diffusion method was applied [12], using EDTA/SMA (Sigma Chemicals) disks $0.4 \mathrm{mM}$ produced in our laboratory. The hydrolytic activity against carbapenems was determined by the Masuda microbiological method [13].
Purified protein was subjected to isoelectric focusing (IEF) as described previously [14]. Blactamases from Klebsiella pneumoniae 185362 were visualized by the iodometric method described by Labia \& Barthélémy [15]. Crude preparations from bacteria possessing Blactamases of known isoelectric points (pl) were used as standards.

Detection of antimicrobial resistance genes was performed by PCR amplification using primers VIM-F (5'-AGTGGTGAGTATCCGACAG-3') and VIM-R (5'-ATGAAAGTGCGTGGAGAC-3') [16] and the GeneAmp PCR reagent kit (Applied Biosystems). DNA templates were prepared by lysing two colonies of the $K$. pneumoniae strain in $100 \mu \mathrm{L}$ of boiling water, and $5 \mu \mathrm{L}$ was used for the PCR. Amplification was performed in a DNA thermal cycler GeneAmp PCR system 2400 (Applied Biosystems) in a final volume of $50 \mu \mathrm{L}$ containing $50 \mathrm{pmol}$ of each primer (Invitrogen), 25 $\mu \mathrm{M}$ of each dNTP, $1.5 \mathrm{mM} \mathrm{MgCl} 2$ and $1 \mathrm{U}$ of Taq polymerase. PCR products were visualized by electrophoresis on $0.8 \%$ agarose gels in TBE buffer ( $\mathrm{pH} 7.0)$ and stained with $1 \%$ ethidium bromide.

The strain showed resistance to Ampicillin, Amoxicillin/Clavulanic Acid, Cefoxitin, Cefotaxime, Ceftazidime, Cefpodoxime, Imipenem, Meropenem, Ciprofloxacin, Gentamicin and Amikacin, remaining susceptible to Aztreonam. The use of the Imipenem-EDTA/SMA double-disk diffusion method and the Masuda method for Imipenem and Meropenem suggested the presence of a metallo- $\beta$-lactamase. The Imipenem and Meropenem MIC were conducted by agar dilution according to CLSI guidelines, resulting in $16 \mu \mathrm{g} / \mathrm{ml}$ (Resistant) for Imipenem, $8 \mu \mathrm{g} / \mathrm{ml}$ (Intermediate) for Meropenem and $0.25 \mu \mathrm{g} / \mathrm{ml}$ (Susceptible). By CLSI MIC determination, Imipenem restored its activity after the addition of EDTA $0.4 \mathrm{mM}$ (from $16 \mu \mathrm{g} / \mathrm{ml}$ to $0.12 \mu \mathrm{g} / \mathrm{ml}$ ) as well as Meropenem (from $8 \mu \mathrm{g} / \mathrm{ml}$ to $0.25 \mu \mathrm{g} / \mathrm{ml}$ ), which confirmed the inhibition of the Imipenem/Meropenem resistance enzyme by EDTA and thus the presence of a metallobetalactamase.

By isoelectric focusing three bands were identified at pl 5.4, 7.6 and 7.9, corresponding to betalactamases without carbapenemase activity, and there was also a band at pl 5.8 with carbapenemase activity that corresponded to the 
MBL. PCR screening of bla genes revealed the presence of blavim, with an amplicon of $261 \mathrm{bp}$.

\section{Discussion}

Panresistant $K$. pneumoniae have been found in the intensive care units of various Athens hospitals since 2001, coinciding with the emergence of MBL-positive enterobacteria [9]. This is the first report of a MBL-mediated carbapenem-resistant Klebsiella pneumoniae in Venezuela, which constitutes a public health concern in our country and requires efficient detection and intervention to preserve antibiotic options. The presence of the resistance enzymes described above in bacteria in our hospitals is of great relevance, since their transfer from $P$. aeruginosa to other microorganisms that also have multiple antibiotic resistance mechanisms (i.e. Enterobacteriaceae) will increase the antimicrobial resistance problem, and this phenomenon is already occurring in some countries with the subsequent rise in health care costs and mortality rates. Tato et al. [17,18] describe an ongoing outbreak of infection and colonization with MBLproducing gram-negative bacteria that is resistant to most widely used antibiotics. They report a situation that is perilously close to a state of endemicity, whereby untreatable organisms are entrenched in their institution, having a mortality rate of almost $50 \%$ among patients who were infected with these organisms [17, 18]. This report, and others like it [18-20], provide an important signal that we need to rapidly attune our surveillance, clinical microbiology, and infection control programs to the coming threat of increasing antibiotic resistance in gram-negative bacilli. It is very important that MBL screening is routinely made to gram-negative bacilli in clinical laboratories, because failure to control outbreaks involving carbapenemase-producing organisms will eventually lead to a situation where all possible empirical treatment options are useless.

\section{References}

1. Giakkoupi P, Tzouvelekis L, Daikos G, Miriagou V, Petrikkos G, Legakis N, Vatopoulos A (2005) Discrepancies and Interpretation Problems in Susceptibility Testing of VIM-1-Producing Klebsiella pneumoniae Isolates. J Clin Microbiology 43(1):494-496.

2. Conceicâo T, Brizio A, Duarte A (2005) First Isolation of blaVIM-2 in Klebsiella oxytoca Clinical Isolates from Portugal. Antimicrobial Agents and Chemotherapy $49(1): 476$.
3. Sánchez D, Marcano D, Spadola E, León L, Payares D, Ugarte C, Salgado N, Maggi G, Guevara A, Torres S, Rodríguez J, Flores A, Tarazona B (2008) Metaloenzimas tipo VIM Detectadas en Aislamientos Clínicos en Pseudomonas aeruginosa en Cuatro Hospitales en Venezuela. Revista Científica del Instituto Nacional de Higiene "Rafael Rangel" (In press).

4. Murphy T, Simm A, Toleman M, Jones R, Walsh T (2003) Biochemical characterization of the adquired Metallo blactamases SPM-1 from Pseudomonas aeruginosa. Antimicrobial Agents and Chemother 47: 582-587.

5. Toleman M, Biedenbach D, Bennett $D$, Jones $R$, Walsh $T$ (2005) Italian metallo $\beta$-lactamases: a national problem? Report from the SENTRY Antimicrobial Surveillance Programme. Journal Antimicrob. Chemother 55: 61-70.

6. Sader H, Castanheira M, Mendes R, Toleman M, Walsh $T$, Jones R (2005) Dissemination and diversity of metalo b-lactamases in Latin America: report from the SENTRY Antimicrobial Surveillance Program. Int J Antimic Agents; 25: 57-61.

7. Peleg A, Franklin C, Bell J, Spelmam D (2005) Dissemination of the metallo $\beta$-lactamase gene bla IMP-4 among gram-negative pathogens in a clinical setting in Australia. Clin. Infect Dis 41: 1549-1556.

8. Mendez R, Castanheira M, Garcia P, Guzman B, Toleran $\mathrm{T}$, Walsh $\mathrm{R}$, Jones $\mathrm{N}$, and SENTRY Antimicrobial Survillance Program (2004) First isolation of blavIM-2 in Latin America: report from the SENTRY Antimicrobial Survillance Program. Antimicrobial Agents and Chemother 48:1433-1434.

9. Miriagou V, Tzelepi E, Daikos G, Tassios P, Tzouvelekis $\mathrm{L}$ (2005) Panresistance in VIM-1 producing Klebsiella pneumoniae. Journal Antimicrob. Chemother. Advance Access publication 16 March 2005

10. Clinical and Laboratory Standards Institute (2003) Performance Standards for Antimicrobial Susceptibility Testing; Approved Standard-Eighth Edition. Volume 23 Number 1. Document M2-A8.

11. Clinical and Laboratory Standards Institute (2003) Methods for Dilution Antimicrobial Susceptibility Tests for Bacteria that Grow Aerobically; Approved StandardSixth Edition. Volume 23 Number 2. Document M7-A6.

12. Lee K, Lim Y, Yong D, Yum J, Chong Y (2003) Evaluation of the Hodge Test and the Imipenem-EDTA Double-Disk Synergy Test for Differentiating Metallo- $\beta$-LactamaseProducing Isolates of Pseudomonas spp. and Acinetobacter spp. J Clin Microbiology 41(10):4623-4629.

13. Masuda G, Tomioka S, Hasegawa M (1976) Detection of $\beta$-lactamase production by gram-negative bacteria. The Journal of Antibiotics, 29 (6): 662-4.

14. Petroni A, Corso A, Melano R, Cacace M, Bru A, Rossi A, Galas M (2002) Plasmidic Extended-Spectrum BLactamases in Vibrio cholerae O1 El Tor Isolates in Argentina". Antimicrobial Agents and Chemother. 46(5):1462-1468.

15. Labia R, Barthélémy $M$ (1979) L'enzymogramme des beta-lactamases: adaptation en cel de la methode iodometrique. Annales de Microbiologie (Paris) 130B, 295-304.

16. Miriagou V, Tzelepi E, Gianneli D, Tzouvelekis LS (2003) Escherichia coli with a self-transferable, multiresistant plasmid coding for metallo-B-lactamase VIM-1. Antimicrob Agents Chemother 47:395-397. 
17. Tato $\mathrm{M}$ et al. (2007) Complex clonal and plasmid epidemiology in the first outbreak of VIM-1 metallo- $\beta$ lactamase involving Enterobacteriaceae in Spain: toward endemicity? Clin Infect Dis 47: 1171-8.

18. Paterson D, Doi Y (2007) A Step Closer to Extreme Drug Resistance (XDR) in Gram-Negative Bacilli. Clin Infect Dis 45: 1179-1181.

19. Bratu S et al. (2005) Rapid spread of carbapenemresistant Klebsiella pneumoniae in New York City: a new threat to our antibiotic armamentarium. Arch Intern Med; 165:1430-1435.

20. Peleg A, Franklin C, Bell J, Spelman D (2005) Dissemination of the metallo- $\beta$-lactamase gene blalMP-4 among gram-negative pathogens in a clinical setting in Australia. Clin Infect Dis 41:1549-56.

Corresponding Author: Daniel Marcano, Sección de Aislamiento e Identificación Bacteriana, Instituto Nacional de Higiene "Rafael Rangel", Caracas, Distrito Capital, Venezuela, Tel: +58-212-2197139; E-mail: danielmarcano2000@yahoo.com

Conflict of interest: No conflict of interest is declared. 